\title{
Comparing the allelopathic potential of exotic and native plant species on understory plants: are exotic plants better armed?
}

Pablo Catalán ${ }^{1,2}$, Beatriz R. Vázquez-de-Aldana ${ }^{3}$, Paloma de las Heras ${ }^{1}$, Alberto Fernández-Seral ${ }^{1}$ \& M. Esther Pérez-Corona ${ }^{1,2}$

1 Departamento de Ecología. Universidad Complutense de Madrid. 28040. Madrid, Spain.

2 Departamento de Matemáticas, Universidad Carlos III de Madrid. 28911 Leganés, Spain.

3 Instituto de Recursos Naturales y Agrobiología de Salamanca. IRNASA-CSIC. 37008.

Correspondence

P. Catalán

E-mail: pcatalan@math.uc3m.es

Teleph. +34 916245960

Received: 2 July 2013

Accepted: 9 September 2013

Published on-line: 20 September 2013

\section{Resumen}

Comparando el potencial alelopático de plantas exóticas y autóctonas sobre las plantas del dosel: ¿están mejor armadas las plantas exóticas?

La alelopatía es un mecanismo clave en las invasiones biológicas. Este estudio se propuso analizar el efecto de extractos acuosos de hojas de tres especies de árboles exóticos comunes en bosques riparios españoles sobre la germinación de seis herbáceas comunes en su sotobosque. Comparamos los efectos de las especies exóticas con los de una especie de árbol nativo, el álamo blanco. Las variables más sensibles a los extractos fueron la velocidad de germinación y el crecimiento radicular, mientras que el porcentaje de germinación apenas fue afectado. Principalmente, los extractos tuvieron un efecto negativo sobre la germinación de todas las especies, excepto Chenopodium album. El álamo blanco causó efectos similares o incluso más negativos que las especies exóticas. Nuestros resultados muestran que la alelopatía es un fenómeno complejo, en el que las especies nativas también están involucradas.

Palabras clave: Porcentaje de germinación, Velocidad de germinación, Extractos foliares, Crecimiento radicular, Zonas de ribera.

\begin{abstract}
Allelopathy is thought to be a key mechanism in biological invasions. Our study aimed to assess the effects of aqueous extracts of leaves from three different exotic tree species common in Spanish riparian forests on the germination of six herbaceous species common in the understory of these ecosystems. We compared the effects of exotic species with those of a native tree species, the white poplar. Our results showed that germination speed and radicle growth of target species were the variables more sensitive to extracts, while percent germination was barely affected. Mostly, extracts had a negative effect on germination speed and radicle growth of all species, except Chenopodium album. White poplar extracts caused similar or even more negative effects than those of the exotic species. Our results show that allelopathy a complex phenomenon, in which native species are also involved.
\end{abstract}

Key words: Percent germination, Germination speed, Leaf extracts, Radicle growth, Riverine areas. 


\section{Introduction}

Biological invasions are one of the biggest problems affecting global biodiversity (Weber, 2003). In terrestrial ecosystems, exotic plants are very effective competitors against native species, decreasing their survival, growth and biomass (Levine et al. 2003, Hager 2004). As a consequence, native plant species end up being excluded by the invaders (Callaway \& Aschehoug 2000), even though most exotic species are not dominant in their natural habitats (Callaway \& Aschehoug 2000).

One of the key mechanisms proposed to account for the invasive plants success is allelopathy (Callaway \& Aschehoug 2000, Hierro \& Callaway 2003, Inderjit et al. 2008), where the released compounds by invaders suppress germination, growth and/or reproduction of native inhabitants of the invaded plant community (Hierro \& Callaway 2003). Furthermore, the released compounds can also affect other processes such as litter decomposition, nutrient recycling or microbial activity (BM. Chen et al. 2009, Barto et al. 2011). Allelochemicals can be released from plants through different mechanisms such a root exudation, leaching of aerial parts, and most notably from decomposing leaf litter (Aldrich 1984, Zamorano 2006).

It has been suggested that allelochemicals released to the environment by invasive species have little or no effect over their original plant communities, but a great effect over invaded communities, because the latter have never been exposed to those particular compounds (the 'novel weapons hypothesis': Callaway \& Aschehoug 2000, Baldwin 2003). One of the most usual ways to assess the allelopathic effect of exotic plant species on native plants is to evaluate their phytotoxic activity through bioassays in which different parameters are measured: germination, plant growth or biomass, under laboratory or greenhouse conditions (e.g. Carballeira \& Reigosa 1999, Lorenzo et al. 2008). When using native plants' seeds, it is common to estimate percent germination (Dias 1991), germination speed (Wardle et al. 1991) or radicle elongation after germination (Dias 1991). This last parameter is not as dependent on the seed's internal resources as the others. In spite of the difficulty of extrapolating the results obtained through these experiments to field conditions, they are essential to quantify the phytotoxic effect of exotic plants (Lorenzo \& González 2010) by isolating the effects of the phytotoxic potential of the plant species from other environmental factors. The extrapolation of the results obtained by these methods to field conditions must be done with caution, as laboratory conditions are a simplification of the processes happening in ecosystems.

Riparian forests are especially sensitive to invasion by exotic plant species, because the dispersion of propagules through them is very simple and fast, given their linearity (Pysek and Prach 1993, 1994, Pysek et al. 1998). Moreover, riparian forests constitute temperate ecosystems with buffered environmental conditions - temperature, light and humidity oscillate much more lightly than outside these systems - and few stressing periods, where alien species can find very favorable scenarios for their successful growth and propagation. In fact, the diversity and abundance of invasive plants has increased in riparian ecosystems throughout the world in recent years (Richardson et al. 2007).

In Spain, concern with invasive species in riparian forests has been growing recently (Enríquez de Salamanca 2009). Exotic tree species like Robinia pseudoacacia L. (Black locust, native to the southeastern USA) or Ulmus pumilla L. (Siberian elm, from Asia) are becoming very frequent in the riverbanks, probably excluding native plants from their habitat (Nasir et al. 2005). Ailanthus altissima (Mill.) Swingle (Tree of heaven, native from China), which also appear on riparian forests, are highly competitive and aggressive, causing autochthonous plants to be excluded through allelopathy (Dana et al. 2004). These invasive species can also affect soil structure, nutrient cycling, and other processes. However, the experiments quantifying the effect of these species on the rest of the plants in the understory community are scarce, and therefore the magnitude and consequences of these invasions at ecosystem level are not clear.

The objective of this study was to determine the allelopathic effect of leaf litter from three different exotic tree species from riparian forests in rivers in central Iberian Peninsula (Spain) (Ailanthus altissima, Robinia pseudoacacia and Ulmus pumilla) and one native plant species (Populus alba L.) on the germination and early radicle 
growth of six herbaceous plant species native from these forests and common in understory communities: Brachypodium phoenicoides (L.) Roem. and Schult., Brachypodium silvaticum (Huds.) Beauv., Chenopodium album L., Dactylis glomerata L., Trifolium pratense L. and Trifolium repens $\mathrm{L}$.

In order to fulfill this objective, we tested whether (a) allelopathic potential differed among tree species and/or differed between exotic and our chosen native species; (b) there were differences in the sensitivity of understory species to tree species; and (c) allelopathy acted the same way on the different processes studied, namely, percent germination, germination speed and early radicle growth.

\section{Materials and Methods}

\section{Study area and plant species}

The study area, with a surface of 79.05 ha, is located at Soto de El Encín (Martínez \& Elorrieta 2000), on the right riverbank of the Henares River, municipality of Alcalá de Henares (Madrid, Spain). The climate is continental Mediterranean, mitigated by the conditions of a riparian zone. The soil is a fluvisol, placed over undifferentiated quaternary materials (Mauri Ablanque et al. 2000). The area keeps a well-conserved riparian forest with reedbeds (Phragmites australis (Cav.) Trin. ex Steud., Typha spp.), willow woods (Salix spp.), poplar groves (Populus spp.), and elm groves ( $\mathrm{Ul}$ mus minor Mill.), although the main formations are P. alba groves (Martínez \& Elorrieta 2000). In some restricted areas, the presence of exotic tree species, such as A. altissima, U. pumilla or $R$. pseudoacacia, has been detected.

In this area, four tree species were selected: the native white poplar $(P . a l b a)$, a deciduous tree distributed by the central and southern Europe, western Asia and northern Africa, and three invasive species. The tree of heaven (A. altissima) is a deciduous tree native from northern China. It is present in the warm and temperate regions of the five continents, where it is used as an ornamental plant. Ailanthus is common in Spain since the beginnings of the 19th century. It has colonized many natural habitats in the Iberian Peninsula, through its high production of seeds (around 35,0000 each year) and its allelopathic effects (Sanz Elorza et al. 2004, GEIB 2006). The black locust ( $R$. pseudoacacia) is also deciduous and native to central U.S.A. It was introduced in Spain in the 18th century, presumably for ornamental use. Since then, it has colonized many areas, including riparian forests, thanks to its vegetative reproduction, nitrogen fixation, and allelopathic effects, among other reasons (Sanz Elorza et al. 2004, GEIB, 2006). Lastly, the Siberian or Russian elm (U. pumilla) is a deciduous tree native from Manchuria which is increasingly colonizing riparian forests (pers. obs.), and to our knowledge there are no reports of its allelopathic potential.

The riverbanks in the study area are very rich in understory species, which are characteristic of these environments (De la Cruz \& Peinado 1996). We selected six herbaceous species from the most frequent in the study area (Martínez \& Elorrieta, 2000): Brachypodium phoenicoides, B. sylvaticum, Dactylis glomerata (Gramineae); Chenopodium album (Chenopodiaceae); and Trifolium pratense and $T$. repens (Leguminosae). Of these species, only C. album is annual, while the others are perennial.

\section{Plant material and preparation of extracts}

During October-November 2009, senescent leaves from P. alba, R. pseudoacacia and U. pumilla were collected from at least 10 trees per species in Soto de El Encín $\left(40^{\circ} 32^{\prime} 15.10^{\prime \prime} \mathrm{N}, 3^{\circ} 16^{\prime} 5.15^{\prime \prime} \mathrm{O}\right)$; Ailanthus leaves were picked up in Ciudad Universitaria, Madrid $\left(40^{\circ} 26^{\prime} 37.88^{\prime \prime} \mathrm{N}, 3^{\circ} 43^{\prime} 36.27^{\prime \prime} \mathrm{O}\right)$. Seeds of the six herbaceous species were obtained commercially (Semillas silvestres S.L.).

Leaves were dried at room temperature and then heated at $65^{\circ} \mathrm{C}$ in an air force oven, until constant weight. Aqueous extracts were prepared by soaking $1 \mathrm{~g}$ of dry leaf litter in $100 \mathrm{~mL}$ of distilled water for 24 hours in an orbital shaker at $80 \mathrm{rpm}$. The resultant solution was filtered with a sterile filter, Millipore Express-Plus $(0.22 \mu \mathrm{m})$ to eliminate organic matter, mineral particles and spores that could interfere with seed germination and radicle elongation results. The extract was diluted with distilled water to 1: $2(50 \%)$ and 1: $5(20 \%)$ in order to obtain 3 applied doses: 100 $(1 \mathrm{~g} / 100 \mathrm{~mL}), \quad 50 \quad(0.5 \mathrm{~g} / 100 \mathrm{~mL})$ and 20 $(0.2 \mathrm{~g} / 100 \mathrm{~mL})$. These doses resembled the average amount of aqueous extracts released by the trees throughout the year, calculated from litter and rainfall ratios (Table 1). Although these doses were calculated to resemble and even surpass 


\begin{tabular}{|c|c|c|c|}
\hline Species & $\begin{array}{c}\text { a Leaf litter } \\
\left(\mathrm{g} \mathrm{m}^{-2} \text { year }^{-1}\right)\end{array}$ & $\begin{array}{c}{ }^{\text {b }} \text { Rainfall } \\
\left(\mathbf{L ~ m}^{-2} \text { year }^{-1}\right)\end{array}$ & $\begin{array}{c}\text { Extract concentration } \\
\left(\mathrm{g} 100 \mathrm{~mL}^{-1}\right)\end{array}$ \\
\hline Ailanthus altissima & 31.6 & 470 & 0.6723 \\
\hline Robinia pseudoacacia* & 7.4 & 470 & 0.1574 \\
\hline Ulmus pumilla & 38.1 & 470 & 0.8106 \\
\hline Populus alba & 41.9 & 470 & 0.8915 \\
\hline
\end{tabular}

${ }^{\mathrm{a} G o n z a ́ l e z-M u n ̃ o z ~ e t ~ a l . ~(2013) ~}$

${ }^{b}$ Martínez and Elorrieta (2000)

*Note that the Robinia pseudoacacia extract used in the experiment was significantly more concentrated than the natural concentration.

Tabla 1. Hojarasca, precipitación y concentración media del extracto en Soto de El Encín, Madrid. Table 1. Leaf litter, rainfall and average extract concentration in Soto de El Encín, Madrid (Spain).

those found in natural conditions, it is true that leaf litter decomposition is a gradual process, and that seeds would probably not encounter such concentrations in the field.

\section{Germination bioassay}

The purpose of this experiment was to examine the effect of leaf litter extracts on percent germination and germination speed of six herbaceous species. For each target species, germination assays were carried out separately. Seeds from the herbaceous species were soaked in water for 24 hours, in order to break their dormancy. For each herbaceous species, 20 seeds were placed on germination paper (Filtros ANOIA S.A.) in Petri dishes ( $9 \mathrm{~cm}$ diameter), each containing $4 \mathrm{~mL}$ of extract for treatments or $4 \mathrm{~mL}$ of distilled water as control. However, we are aware of the limitations of the use of distilled water as a control (Wardle et al., 1992). The experimental design had two factors: Tree species factor with four levels, $P$. alba $(\mathrm{Pa})$, A. altissima $(\mathrm{Aa})$, R. pseudoaacia $(\mathrm{Rp})$ and U. pumilla (Up), and Dose factor with three levels, $20 \%, 50 \%$ and $100 \%$. This made a total of 13 treatments: Control, Pa20, Pa50, Pa100, Aa20, Aa50, Aa100, Rp20, Rp50, Rp100, Up20, Up50 and Up100. There were three replicates per treatment, making a total of 39 Petri dishes per target species. This design was replicated with every herbaceous species. Dose 20 could not be applied to B. sylvaticum due to lack of available seeds. Petri dishes were randomly placed in a germination chamber, in dark, at $24{ }^{\circ} \mathrm{C}$. The Petri dishes were moistened with distilled water when necessary. During 30 days, germinated seeds were daily counted in order to get two variables: percent germination (final number of germinated seeds x 100 /total seeds) and germination speed, calculated using the index provided by Einhellig et al. (1982):

$$
S=\left[N_{1}+\frac{N_{2}-N_{1}}{2}+\frac{N_{3}-N_{2}}{3}+\ldots+\frac{N_{n}-N_{n-1}}{n}\right] \cdot 100
$$

Where $\mathrm{N}_{1}, \mathrm{~N}_{2}, \mathrm{~N}_{3}, \mathrm{~N}_{\mathrm{n}}$ represent the proportion of germinated seeds in day $1,2,3 \ldots \mathrm{n}$ after the start of the experiment. $\mathrm{S}$ varies from 0 (if no seeds germinate by the end of the experiment) to 100 (if all seeds germinated on the first day).

\section{Radicle growth bioassay}

This experiment tested the effects of leaf litter extracts on radicle growth of herbaceous species. Four target species were considered: T. repens, $T$. pratense, C. album and D. glomerata. After breaking their dormancy in the same way as in the previous experiment, seeds were put in plates with perlite bottom covered with moistened filter paper. After 48-72 hours, several germinated seeds from $1 \mathrm{~mm}$ maximum radicle length were selected and put on a Petri dish on germination paper soaked in $4 \mathrm{ml}$ of plant extract. The treatments were applied following the same experimental design as that used in the germination assay, that is, a factorial combination of four tree species and three doses. There were 39 dishes for each target species, except from C. album, in which Dose 20 and Dose 50 could not be studied. Petri dishes were incubated at $24^{\circ} \mathrm{C}$ in darkness. Radicle length was recorded after 48 hours by scanning the seedlings with a deskscan. Length measurements were obtained from digital images using Photoshop CS4 (Adobe).

\section{Data analysis}

Allelopathic effects on the germination rate, ger- 
mination speed and radicle growth were studied by two-way ANOVA, using Tree species and Dose as fixed factors. Significant differences $(p<0.05)$ between groups were studied using Tukey's HSD test. As we could only study one Dose level for C. album, the differences between tree species were studied using a one-way ANOVA.

Differences between treatments and control mean values were tested using Dunnett's test (one-way ANOVA). Homocedasticity assumption was verified in all cases using Bartlett's test $(\mathrm{p}>0.05)$, so variable transformation was not needed.

All statistical analyses were made using statistical program package STATISTICA 6.0 for Windows (Statsoft).

\section{Results}

\section{Percent germination}

Only two species were significantly affected by the extracts: B. sylvaticum and T. repens (Fig. 1). Dose factor had a significant effect on $B$. sylvaticum, with an interaction between Dose and Tree Species. B. sylvaticum showed a significant response to Pa100, Aa100 and Rp50 (although Rp 100 showed no effect). Dose factor had a significant effect on $T$. repens. It showed a significant reduction of percent germination under Pa100 and Rp100 treatments.

Differences between doses were significant only for the same two species (Fig. 1). B. sylvaticum showed lower germination under Pa100 and Aa100 than Pa50 and Aa50, respectively. These treatments showed lower percent germination rates than the other tree species at the any concentration. The percent germination of $T$. repens was lower for $\mathrm{Rp} 100$ than for $\mathrm{Rp} 20$.

\section{Germination speed}

There were more significant effects of plant extracts on germination speed than on percent germination (see above; Fig. 2). The species $B$. phoenicoides, B. sylvaticum, D. glomerata, T. pratense and $T$. repens showed significant differences between control and dose extract treatments for several tree species. Dose factor had significant effects on B. phoenicoides, B. sylvaticum, T. pratense and $T$. repens. Tree species factor had signi- ficant effects on B. phoenicoides, B. sylvaticum, $D$. glomerata, T. pratense and T. repens. There was a significant interaction between the two factors in $B$. phoenicoides. We found an increase of germination speed in $B$. phoenicoides under Up20 when comparing with the control.

Moreover, B. phoenicoides suffered a decrease in germination speed under Pa100; B. sylvaticum under Pa100 and Aa100; D. glomerata under Pa20, Pa50, Pa100, Aa50 and Aa100; and T. repens under Pa20, Pa100, Aa100 and Rp100. Extracts of $P$. alba and A. altissima affected germination of several understory species (4 and 3 herbaceous plant species, respectively) whereas $U$. pumilla and $R$. pseudoacacia only affected one species.

Significant dose effects were scarce since only Up50 and Up100 were different than Up20 for B.phoenicoides and Rp50 and Rp100 were different than Rp20 for T. repens. C. album germination speed showed no effect of any tree species extract or doses.

\section{Radicle growth}

Extract treatments had effect on radicle growth of three of the four herbaceous species studied, except $C$. album (Fig. 3). Dose factor had a significant effect on both $T$. pratense and $T$. repens, whereas Tree species had a significant effect on $D$. glomerata and T. repens. There were no significant interactions between the two factors. When the effects were significant, radicle growth was always reduced when comparing with control treatment values. The radicle growth of $T$. pratense showed lower values for any tree extracts treatment than for the control, although there were no differences between extract doses. Three tree species extracts at any doses (P. alba, U. pumilla and $R$. pseudoacacia) produced a reduction of radical growth of $D$. glomerata with respect to control. No significant differences among doses were found. Pa50, Pa100, Up100 and Rp100 reduced radicle growth of $T$. repens in respect to control. No significant differences among doses were found. A. altissima produced effects only in T. pratense whereas $P$. alba, U. pumilla and $R$. pseudoacacia affected radicle growth of D. glomerata, $T$. pratense and $T$. repens.

Comparing the three variables studied, radicle growth was affected in more treatments, followed by germination speed. Percent germination was 
a. Chenopodium album

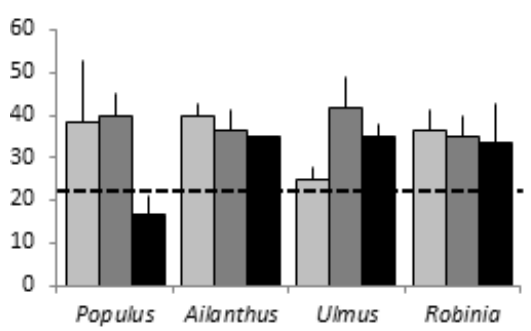

c. Brachypodium sylvaticum

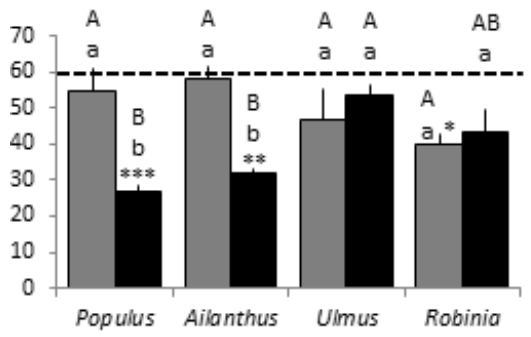

e. Trifolium pratense

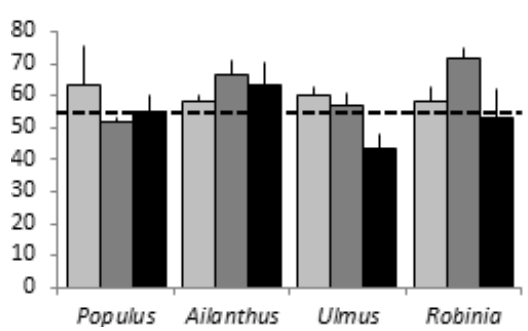

b. Brachypodium phoenicoides

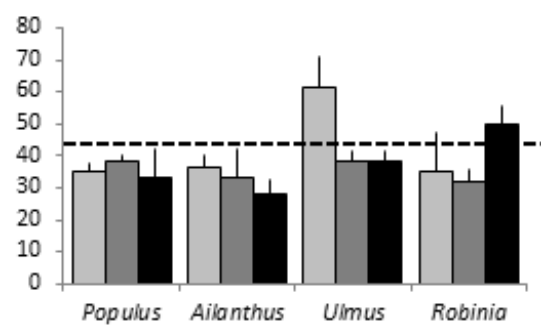

d. Dactylis glomerata

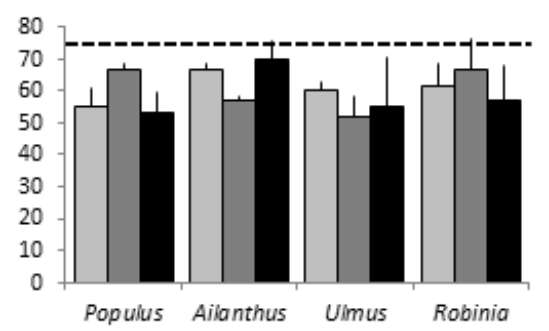

f. Trifolium repens



Figura 1. Porcentaje de germinación (media \pm error estándar, $n=3$ ) de especies herbáceas afectadas por diferentes dosis (Gris claro: $20 \%$, Gris oscuro: $50 \%$, Negro: $100 \%$ ) de los extractos de las cuatro especies arbóreas. Mayúsculas indican diferencias significativas entre especies arbóreas para la misma dosis, y minúsculas indican diferencias significativas entre dosis para la misma especie de árbol ( $\alpha=0.05$, test $\mathrm{HSD}$ de Tukey). La ausencia de letras indica ausencia de diferencias significativas entre grupos. Los asteriscos indican diferencias significativas con el control: $*=$ Significativo $(\mathrm{p}<0.05) ; * *=$ Muy significativo $(\mathrm{p}<0.01), * * *=$ Extremadamente significativo $(\mathrm{p}<0.001)($ test de Dunnett). Línea discontinua: media del control.

Figure 1. Percent germination (means \pm standard error, $n=3$ ) of herbaceous species as affected by different doses (Light grey: $20 \%$; Dark grey: 50\%; Black: 100\%) of litter extracts from four tree species. Capital letters indicate significant differences between tree species for the same dose and lower case letters indicate significant differences between doses in the same tree species ( $\alpha=0.05$, Tukey's HSD test). No letters show no significant differences among groups. Asterisks indicate significant differences with the control: $*=$ Significant $(\mathrm{p}<0.05$ ); $* *=$ Highly significant $(\mathrm{p}<0.01), * * *=$ Extremely significant $(\mathrm{p}<0.001)$ (Dunnett's test). Dashed line: control means.

found to be less responsive to the extracts obtained from the tree species.

\section{Discussion}

Our study aimed to determine the allelopathic effect of leaf litter from four tree species (three exotic and one native) on the germination of six herbaceous species from the understory of riparian forests. We measured percent germination, germination speed and radicle growth using three different doses from leaf extracts. Overall, our results showed that percent germination was less af- fected than germination speed and radicle growth and that Populus alba, the native species, had the most intense allelopathic effect.

\section{Germination rates and radicle growth}

We observed that percent germination was not significantly affected by the allelopathic extracts in most cases. This would suggest that our extract concentrations were not high enough to cause effects. However, these concentrations were calculated to resemble and even surpass field conditions (Table 1), so this hypothesis has to be ruled out. Besides, the existence of allelopathic effects 
a. Chenopodium album

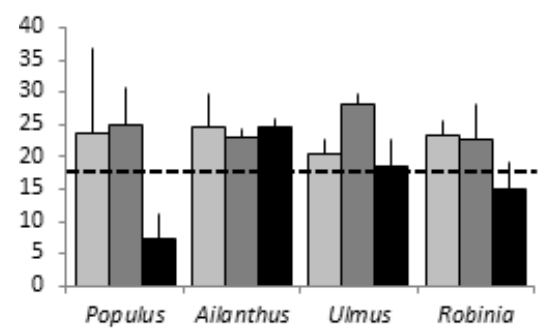

c. Brachypodium sylvaticum



e. Trifolium pratense

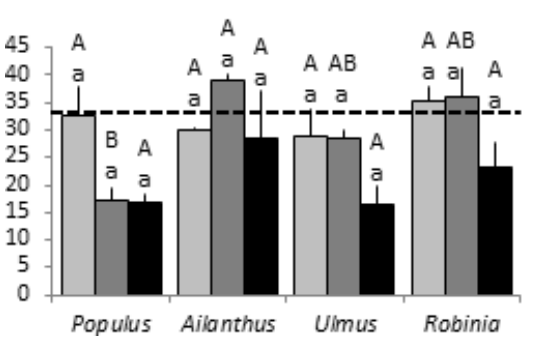

b. Brachypodium phoenicoides

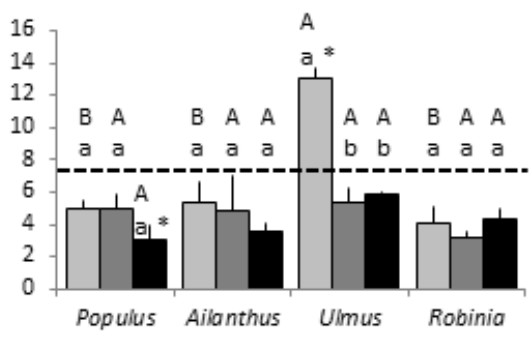

d. Dactylis glomerata

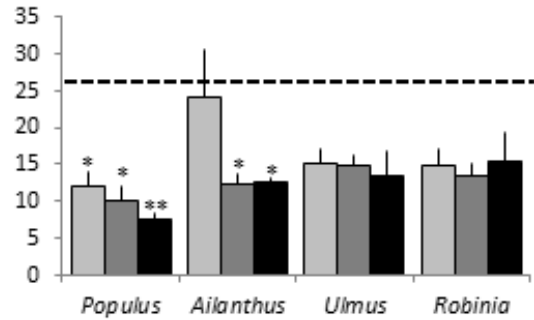

f. Trifolium repens



Figura 2. Velocidad de germinación (media \pm error estándar, $n=3$ ) de especies herbáceas afectadas por diferentes dosis (Gris claro: 20\%, Gris oscuro: 50\%, Negro: $100 \%$ ) de los extractos de las cuatro especies arbóreas. Línea discontinua: media del control.

Figure 2. Germination speed (means \pm standard error, $n=3$ ) of herbaceous species as affected by different doses (Light grey: 20\%; Dark grey: $50 \%$; Black: $100 \%$ ) of litter extracts from four tree species. Dashed line: control means.

at these concentrations was evident in the other two variables studied (germination speed and radicle growth).

Germination speed and radicle growth of most herbaceous species were negatively affected by the treatments, except $C$. album (in which both speed and radicle growth were unaffected) and $T$. pratense (in which only radicle growth was affected). In many cases, a concentration-dependent inhibitory effect was evident, as can be seen in the results section (significant effects of the Dose factor). This has been previously reported (Tawaha \& Turk 2003, Dorning \& Cipollini 2006).

As percent germination was almost unaffected, the sensitivity of germination speed to the litter extracts would indicate that nearly all seeds germinate in the end, but do so with some delay.

The sensitivity of radicle growth to the in- hibitory effect of the extracts has more ecological relevance because it does not dependend only on the seed's internal resources, but also on the nutrients that the seed is able to absorb from its surroundings. Roots are more sensitive to allelopathic extracts than other parts of the plant (Tawaha \& Turk, 2003; Wakjira et al., 2005), as they are the first to come in contact with allelochemicals. The delay in radicle growth could have relevant effects on seedling survival, and subsequently on community composition and diversity. Therefore, radicle growth as an index could be more easily related to the ecological effects of allelopathy.

Our results suggest that percent germination is less sensitive to allelopathic effects, in spite of its widespread use in allelopathy bioassays (Lorenzo \& González 2010), in agreement with the results 

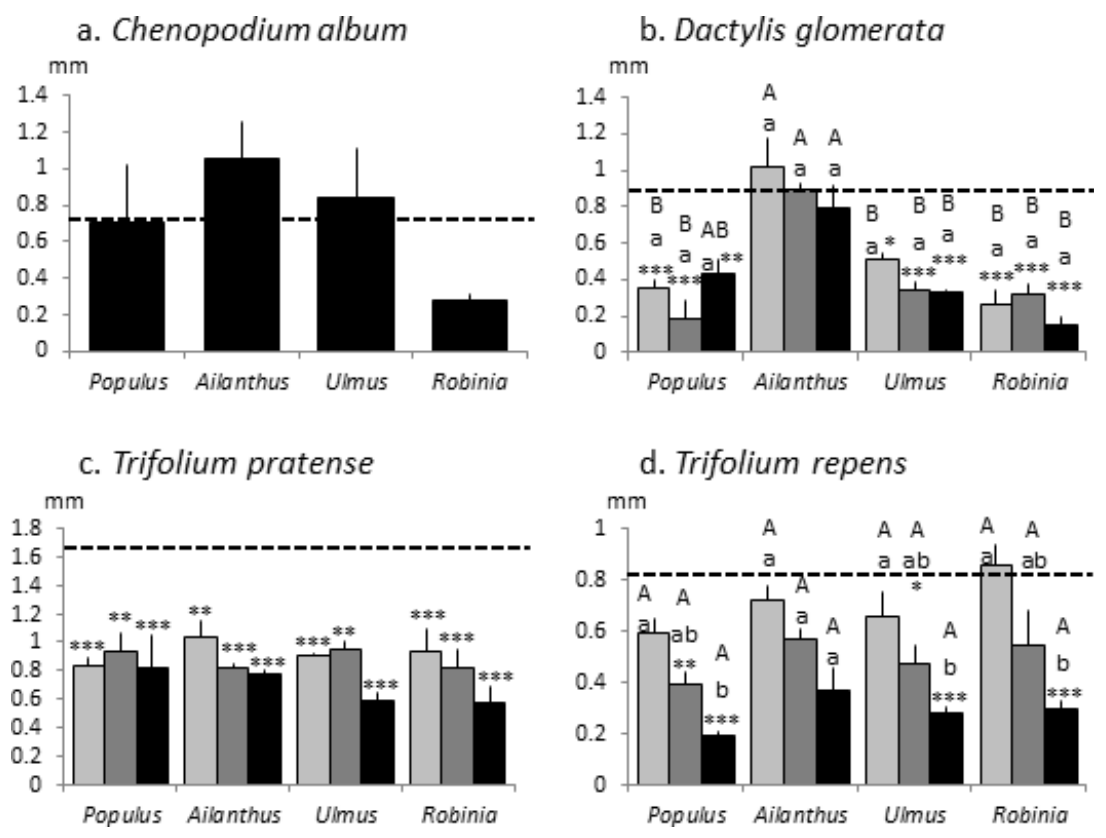

Figura 3. Crecimiento radicular (media \pm error estándar, $n=3$ ) de especies herbáceas afectadas por diferentes dosis (Gris claro: 20\%, Gris oscuro: $50 \%$, Negro: $100 \%$ ) de los extractos de las cuatro especies arbóreas. Línea discontinua: media del control.

Figure 2. Radicle growth (means \pm standard error, $n=3$ ) of herbaceous species as affected by different doses (Light grey: 20\%; Dark grey: $50 \%$; Black: $100 \%$ ) of litter extracts from four tree species. Dashed line: control means.

of Chiapusio et al. (1997) and Hussain et al. (2011). Moreover, the validity of this index as a measure of allelopathy has been called into question (Hussain et al. 2011). Therefore, we strongly recommend the use of more parameters than just germination percentage to measure allelopathic effects.

\section{Responses of herbaceous species}

The effect of allelopathy in community structure depends on the sensitivity or tolerance of the different species to the litter extracts. Our experiments showed that the same tree species affected herbaceous species in a different way. Thus, $T$. repens and B. sylvaticum were the most sensitive species in all cases. In $T$.pratense, radicle growth was greatly inhibited, but percent germination was not affected, which could have different ecological consequences depending on when and how long the allelochemical compounds are released in natural conditions. A special case is C. album, whose percent germination, germination speed and radicle growth was equal or higher (although not significantly) than the control. This result can be related with some of typical characteristics of the species, such as its life story. Annual species, such as C. album, may use the contact with allelochemical compounds as a signal to end their dormancy and germinate (Preston \& Baldwin 1999).

\section{Allelopathic potential in exotic and native plants}

Contrary to our expectations, when comparing the effects of the extracts on one herbaceous species, we found that poplar extracts usually had the same or even stronger effects than the exotic tree species extracts. This could indicate a higher sensitivity to poplar allelochemicals, which is a native tree species. The allelopathic capacity of native species has been previously reported (Newman 1978, Chivas \& Escudero 1997, Valera-Burgos et al. 2012), showing that long coexistence does not necessarily result in species becoming more tolerant to each other's allelochemicals. Although allelopahy has been suggested as a mechanism for exotic plant invasion (Kruse et al. 2000, Hierro \& Callaway 2003), our results suggest otherwise, as $P$. alba, a native tree can be as allelopathic as them or, in some cases, even more. The broadening of these results to other native tree species should be considered to infere a more general pattern of the tree influence on understory communities that lead to more relevant conclusions at ecosystem level.

Litter from the four tree species studied had inhibitory effects on one or more herbaceous species which could be mediated through substances present in the aqueous extracts of leaves, i.e., allelochemicals. Different allelochemicals 
have been isolated from these species. Ailanthus extracts contain ailanthone, a phytotoxical metabolyte present in bark, branches and leaves (Heisey 1997), although the mechanisms through which it inhibits germination and radicle growth are yet unknown. Black locust leaves contain robinetin, myricetin and quercetin (Nasir et al. 2005), which inhibit shoot and root growth. Poplar produces abundant secondary metabolites such as flavonoids and terpenoids, which appear in bark, branches and leaves and inhibit germination and growth of other plants around the tree (F. Chen et al., 2009). The phytotoxic capacity of Siberian elm has not been reported previously, and in our study this species had the least inhibitory effect.

\section{Conclusions}

Allelopathic effects have been studied as a possible mechanism contributing to the large success of invasive species in new environments and specially in highly vulnerable ecosystems i.e. riparian forest. Our results suggest that allelopathy is a complex phenomenon, in which native species are also involved. The outcome of the interaction between native and exotic plants' allelopathy will depend on many factors, including community richness, environmental stress, and so on. Further research is being done by our group taking into account community dynamics and native-exotic competition, in order to better understand the role of allelopathy in biological invasions.

Summing up our initial questions, we have observed that there are differences in the allelopathic potential between tree species, but these differences are not qualitatively different between native and exotic species. Furthermore, herbaceous species were not equally sensitive to the aqueous extracts of the tree species. Finally, allelopathy did not uniformly affect the different processes studied, with radicle growth as the most affected variable.

\section{Acknowledgements}

This work was funded by project POII10-01794700 of the Junta de Comunidades de Castilla La Mancha. We are also indebted to the Comunidad de Madrid (project REMEDINAL, S-0505/AMB/
0335) and Universidad Complutense-Banco Santander (Research Groups Founding 2010-group 910314)

\section{References}

Aldrich JD. 1984. Weed-crop ecology: Principles and practices. Breton Publishers. Pp 215-241.

Baldwin IT. 2003. At last, evidence of weapons of mass destruction. Science STKE 203: pe42.

Barto E, Antunes PE, Stinson K, Koch AM, Klironomos JN \& Cipollini D. 2011. Differences in arbuscular mycorrhizal fungal communities associated with sugar maple seedlings in and outside of invaded garlic mustard forest patches. Biological Invasions 13: 2755-2762.

Callaway RM \& Aschehoug ET. 2000. Invasive plants versus their new and old neighbors: a mechanism for exotic invasion. Science 290: 521-523.

Chen BM, Peng SL \& Ni GY. 2009. Effects of the invasive plant Mikania micrantha H.B.K. on soil nitrogen availability through allelopathy in South China. Biological Invasions 11: 1291-1299.

Chen F, Liu CJ, Tschaplinski TJ \& Zhao N. 2009. Genomics of secondary metabolism in Populus: interactions with biotic and abiotic environments. CRC Critical Reviews in Plant Sciences 28: 375-392.

Chiapusio G, Sánchez-Moreiras AM, Reigosa MJ, González L \& Pellissier F. 1997. Do germination indices adequately reflect allelochemical effects on the germination process? Journal of Chemical Ecology: 2445-2453.

Dana ED, Sobrino E \& Sanz-Elorza M. 2004. Plantas invasoras en España: un nuevo problema en las estrategias de conservación. In: Bañares A et al. eds. Atlas y libro rojo de la flora vascular amenazada de España. Taxones prioritarios. Dirección General de Conservación de la Naturaleza, Madrid, pp 10101029.

De la Cruz M \& Peinado M. 1996. El paisaje vegetal de la cuenca del Rio Henares. I. Comunidades arbóreas y arbustivas. Revista de estudios de Guadalajara 23: 335-396.

Dias LS. 1991. Allelopathic activity of decomposing straw of wheat and oat and associated soil on some crop species. Soil \& Tillage Research 21: 113-120.

Dorning M \& Cipollini D. 2006. Leaf and root extracts of the invasive shrub, Lonicera maackii, inhibit seed germination of three herbs with no autotoxic effects. Plant Ecology 184: 287-296.

Einhellig FA, Schon MK \& Rasmussen JA. 1982. Synergistic effects of four cinnamic acid compounds on grain sorghum. Journal of Plant Growth Regulation 1: $251-258$.

Enríquez de Salamanca A. 2009. Especies vegetales exóticas en cauces y riberas. Asociación y Colegio Oficial de Ingenieros Técnicos Forestales Revista Foresta. No 41 , pp 58-69.

GEIB. 2006. TOP 20: Las 20 especies exóticas invasoras más dañinas presentes en España. GEIB, Serie 
Técnica $\mathrm{N}^{\circ} 2$.

González-Muñoz N, Castro-Díez P \& Parker IM. 2013. Differences in nitrogen use strategies between native and exotic tree species: predicting impacts on invaded ecosystems. Plant and Soil 363 (1-2): 319329

Grant DW, Peters DPC, Bech GK \& Fraleigh H D. 2003. Influence of an exotic species, Acroptilon repens (L.) D.C. on seedling emergence and growth of native grasses. Plant Ecology 166: 157-166.

Hager HA. 2004. Competitive effect versus competitive response of invasive and native wetland plant species. Oecologia 139: 140-149.

Heisey RM. 1997. Allelopathy and the secret life of Ailanthus altissima. Arnoldia 28: 35.

Hierro JL \& Callaway RM. 2003. Allelopathy and exotic plant invasion. Plant and Soil 256: 29-39.

Hussain ML, González L \& Reigosa MJ. 2011. Allelopathic potential of Acacia melanoxylon on the germination and root growth of native species. Weed Biology and Management 11: 18-28.

Inderjit, Seastedt TR, Callaway RM, Pollock JL \& Kaur J. 2008. Allelopathy and plant invasions: Traditional, congeneric, and bio-geographical approaches. Biological Invasions 10: 875-890.

Kruse M, Strandberg M \& Strandberg B. 2000. Ecological effects of allelopathic plants - a review. NERI Technical Report No. 315. National Environmental Research Institute, Silkeborg, Denmark.

Levine JM, Vilà M, D'Antonio CM, Dukes SM, Grigulis K and Lavorel S. 2003. Mechanisms underlying the impacts of exotic plant invasions. Proceedings of the Royal Society of London B Biology 270: 775-781.

Lorenzo P \& González L. 2010. Alelopatía: una característica ecofisiológica que favorece la capacidad invasora de las especies vegetales. Ecosistemas 19 (1): 79-91.

Lorenzo P, Pazos-Malvido E, González L \& Reigosa MJ. 2008. Allelopathic interference of invasive Acacia dealbata: physiological effects. Journal 22 (2): 6476.

Martínez T \& Elorrieta I. 2000. El Soto de El Encín. Dirección General de Agricultura y Alimentación, Comunidad de Madrid.

Mauri Ablanque PV, Bienes Allas R et al. 2000. "El Encín”: clima, suelo y vegetación. IMIDRA, Comunidad de Madrid.

Nasir H, lqbal Z, Hiratade S \& Fujii Y. 2005. Allelopathic potential of Robinia pseudo-acacia L. Journal of Chemical Ecology 31 (9): 2179-2192.

Newman El. 1978. Allelopathy: adaptation or accident? In: Harborne JB. ed. Biochemical aspects of plant and animal coevolution. Academic Press, New York.
Preston CA \& Baldwin IT. 1999. Positive and negative signals regulate germination in the post-fire annual, Nicotiana attenuata. Ecology 80: 481-494.

Pysek P \& Prach K. 1993. Plant invasions and the role of riparian habitats - a comparison of four species alien to central Europe. Journal of Biogeography 20: 413-420.

Pysek P \& Prach K. 1994. How important are rivers for supporting plant invasions? In: De Waal LC, Child EL, Wade PM, \& Brock JH. eds. Ecology and management of invasive riverside plants. J Wiley \& Sons, pp 19-26.

Pysek P, Prach K, \& Mandák B. 1998. Invasions of alien plants into habitats of Central European landscape: an historical pattern. In: Starfinger U, Edwards K, Kowarik I \& Williamson M. eds. Plant invasions: Ecological mechanisms and human responses. Backhuys Publishers, Leiden, pp 23-32.

Richardson DM, Holmes PM, Elser KJ, Galatowitsch SM, Stromberg JC, Kirkman SP, Pysek P \& Hobbs RJ. 2007. Riparian vegetation: degradation, alien plant invasions, and restoration prospects. Diversity and Distributions 13: 126-139.

Sanz Elorza M, Dana Sánchez ED \& Sobrino Vesperinas E. eds.. 2004. Atlas de las plantas alóctonas invasoras en España. Dirección General para la Biodiversidad, Madrid.

Tawaha AM \& Turk MA. 2003. Allelopathic effects of black mustard. Brassica nigra on germination and growth of wild barley. Hordeum spontaneum. Journal of Agronomy and Crop Science 189: 298-303.

Valera-Burgos J, Díaz-Barradas MC \& Zunzunegui M. 2012. Effects of Pinus pinea litter on seed germination and seedling performance of three Mediterranean shrub species. Plant Growth Regulation 66: 285-292.

Wakjira M, Berecha G \& Bulti B. 2005. Allelopathic effects of Parthenium hysterophorus extracts on seed germination and seedling growth of lettuce. Tropical Science 45 (4): 159-162.

Wardle DA, Ahmed M \& Nicholson KS. 1991. Allelopathic influence of nodding thistle. Carduus nutans L. seeds on germination and radicle growth of pasture plants. New Zealand Journal of Agricultural Research 34: 185-191.

Wardle DA, Nilsson MC, Gallet C \& Zackrisson O. 1992 An ecosystem-level perspective of allelopathy. Biological Reviews of the Cambridge Philosophical Society $73:$ 305-319.

Weber E. 2003. Invasive plant species of the World. A reference guide to environmental weeds. $\mathrm{CABI}$ Publishing. Wallingford. U.

Zamorano C. 2006. Alelopatía: un nuevo reto en las ciencias arvenses en el trópico. Agron 14 (1): 7-15. 